\title{
Impact of mechanical stratification on the structural style of the Lublin Basin, SE Poland: results of seismic interpretation and implications for quantification of deformation within the frontal parts of thin-skinned fold-and-thrust belts
}

\author{
Mateusz Kufrasa $^{1}$ (D) P Piotr Krzywiec ${ }^{1}$ (D)
}

Received: 29 September 2020 / Accepted: 18 November 2021 / Published online: 30 November 2021

(c) The Author(s) 2021

\begin{abstract}
We demonstrate how lithological and mechanical stratification of Ediacaran-Carboniferous sedimentary package governs strain partitioning in the Lublin Basin (LB) which was incorporated in the marginal portion of the Variscan fold-and-thrust belt. Based on the geometry of seismic reflectors, the pre-Permian-Mesozoic sedimentary sequence was subdivided into two structural complexes differing in structural style. The lower one reveals forelandward-vergent imbrication, while the upper one comprises fold train, second-order deformations, and multiple local detachments. Lithological composition of the upper structural complex controlled geometry, kinematics, and position of compressional deformations in stratigraphic profile. System of foreland-vergent thrusts which links lower and upper detachment developed due to efficiency of simple shear operating in heterogeneous clastic-carbonate-evaporitic strata of the Lower-Upper Devonian age. Internal homogeneity promoted the formation of conjugate sets of thrusts in Silurian shales and Upper Devonian limestones. Structural seismic interpretation combined with sequential restoration revealed localised thickening of Devonian strata and up to 5\% difference in length of Devonian horizons. This mismatch is interpreted as a manifestation of distributed shortening, including layerparallel shortening (LPS), which operated before or synchronously to the initiation of folding. The amount of distributed strain is comparable with numbers obtained in external parts of other fold-and-thrust belts. The outcomes derived from this study may act as a benchmark for studying variability in a structural style of multilayered sequences which were incorporated in the external portion of other fold-and-thrust belts.
\end{abstract}

Keywords Layer-parallel shortening $\cdot$ Strain partitioning $\cdot$ Variscan deformation $\cdot$ Thin-skinned tectonics $\cdot$ Cross-section restoration · Lublin Basin

\section{Introduction}

External portions of fold-and-thrust belts (FTBs) have been extensively investigated, as their minor erosion and relatively low degree of deformation reduce interpretation uncertainty and offer an opportunity for studying a range of deformation processes, including layer-parallel shortening (LPS), buckling, folding and fault-related thrusting. Layer-parallel shortening starts to operate at the very early stage of deformation and may be obscured by later

Mateusz Kufrasa

mateusz.kufrasa@twarda.pan.pl

Institute of Geological Sciences, Polish Academy of Sciences, 51/55 Twarda Street, 00-818 Warsaw, Poland processes. This mode of deformation leads to loss of a rock volume by porosity reduction, formation of pressure solution cleavage or stylolitization, and effects of this phenomenon can be observed at micro- or outcrop-scale. Later, when the compression axis is still oriented parallel to the layer boundaries, LPS is followed by buckle folding, which results in the development of a fold train due to amplification of pre-existing mechanical inhomogeneity in a rocks mass (Ramsay 1967). Buckle folds may develop both at the scale of an outcrop, or seismic profile (e.g. Konon 2006; Butler et al. 2019). Finally, anticlines and synclines may form in response to movement of material over curved fault surface, or develop due to strain accommodation in front of propagating fault (see Storti et al. 1997; Tavarnelli 1997; Brandes and Tanner 2014 and references therein; Butler et al. 2019). 
The deformation processes that govern the structural pattern of strata in front of advancing tectonic wedge may be reduced to two end-members: thrust imbrication and distributed shortening. The former works effectively in layered rocks and favours flexural-slip folding or imbrication, while the latter operates in homogeneous beds and promotes the formation of neutral-surface folding or formation of conjugate thrusts (Ramsay 1967; Price and Cosgrove 1990). Their occurrence in a stratigraphic sequence is controlled by the lithological composition of host rocks and resultant mechanical stratification (e.g. Stockmal et al. 2001; Le Garzic et al. 2019).

In cases of underexplored FTBs, concealed beneath a younger sedimentary cover, seismic reflection data may be the only source of information on style and degree of deformation. This method, however, offers much lower resolution in comparison to observations in field outcrops, core samples, or thin sections. Therefore, cross-sections built upon seismic data are capable to unravel geometry and structural evolution of first-order deformations, and capture shortening associated with major folds and thrusts only, neglecting other smaller-scale deformations that are at or below seismic resolution (Fig. 1; Woodward et al. 1989; Saura et al. 2008; Moretti and Callot 2012; Cardozo and Brandenburg 2014; Hughes and Shaw 2014).

This study presents an attempt to relate vertical variation of the structural style resolved by seismic data to change in the lithological composition of Ediacaran-Carboniferous strata of the Lublin Basin (LB) that were involved in late Carboniferous thin-skinned folding and thrusting as the frontal part of the Variscan orogen was emplaced above the SW slope of the East European Craton (EEC, Fig. 2; Krzywiec et al. 2017a, b; Mazur et al. 2018; Kufrasa et al. 2020). The interpretation of high-resolution seismic data was carried out and combined with structural sequential restoration of both long- and short-wavelength structures to verify the admissibility of the cross-section. High-quality seismic

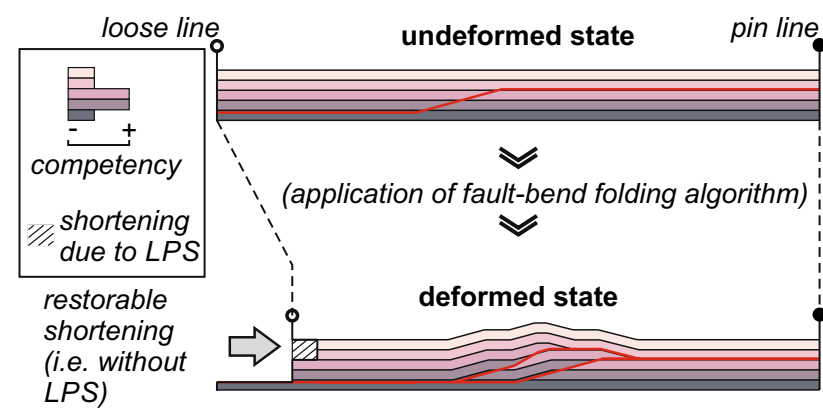

Fig. 1 Conceptual model of forward modelling using fault-bend folding algorithm; the amount of a horizontal shortening is equal to the difference in horizontal length of horizons in undeformed and deformed states imaging and a low degree of deformation make this area suitable for studying the occurrence of distributed shortening and thrust imbrication within different lithological units. Mechanical stratification of rocks subjected to Variscan shortening favoured the development of multiple detachments in Ediacaran-Carboniferous strata. Variable lengths of the restored horizons have been interpreted as a result of layer-parallel shortening (LPS). The estimates of penetrative strain obtained in this study were then compared to results of LPS analyses performed in frontal parts of other FTBs.

\section{Geological setting}

SW slope of the East European Craton, where the LB is located, and within which the frontal part of the Variscan FTB is situated, was subjected to multiple geodynamic processes since Neoproterozoic-Palaeozoic. This multi-stage evolution is recorded in vertical lithological-mechanical heterogeneity of the Ediacaran-Carboniferous sedimentary infill of the LB (Fig. 3). The oldest tectonic event related to the Rodinia breakup is evidenced by a system of normal faults and related half-grabens filled with syn-kinematic clastic and volcanic rocks (Pacześna and Poprawa 2005; Krzywiec et al. 2018a, b; Poprawa et al. 2020). The Cambrian-Ordovician post-rift thermal subsidence and ensuing development of the Peri-Tornquist Ocean are recorded by a sequence of shallow-marine mudstones, sandstones and carbonates. Vertical load exerted by docking of Avalonia to the EEC led to basement flexure and deposition of $>3 \mathrm{~km}-$ thick succession of the Silurian shales in a Caledonian foreland basin. Since the Early Devonian, a transition to terrigenous sedimentation is expressed by coarsening-upward sedimentary sequence attaining $2 \mathrm{~km}$ of the total thickness (Narkiewicz 2007). Middle-Late Devonian shallow-marine sedimentation was controlled by eustatic sea-level changes. Thin (i.e. up to $200 \mathrm{~m}$ ) Middle Devonian strata consists of carbonate-clayey rocks that pass upward into carbonates and anhydrites. It is overlain by a much thicker $(>2 \mathrm{~km})$ package of limestones, dolostones and marly limestones (Narkiewicz 2011). As a result of Late Devonian-early Carboniferous tectonic activity, the LB was split into blocks bounded by high-angle reverse faults (e.g. Krzywiec et al. 2017b; Kufrasa et al. 2018, 2019). The unconformity that developed at that time was then covered with up to $2 \mathrm{~km}$-thick suite of the Mississippian-Pennsylvanian shallow-marine to fluvial clastics that contain thin limestone layers and coal seams (e.g. Waksmundzka 2013; Kozłowska and Waksmundzka 2020; Waksmundzka et al. 2021).

Prior to the onset of Permian-Mesozoic sedimentation the area of LB was subjected to major contractional deformation caused by the collision of Gondwana with the EEC (Krzywiec et al. 2017a, b; Mazur et al. 2018, 2020 and references 


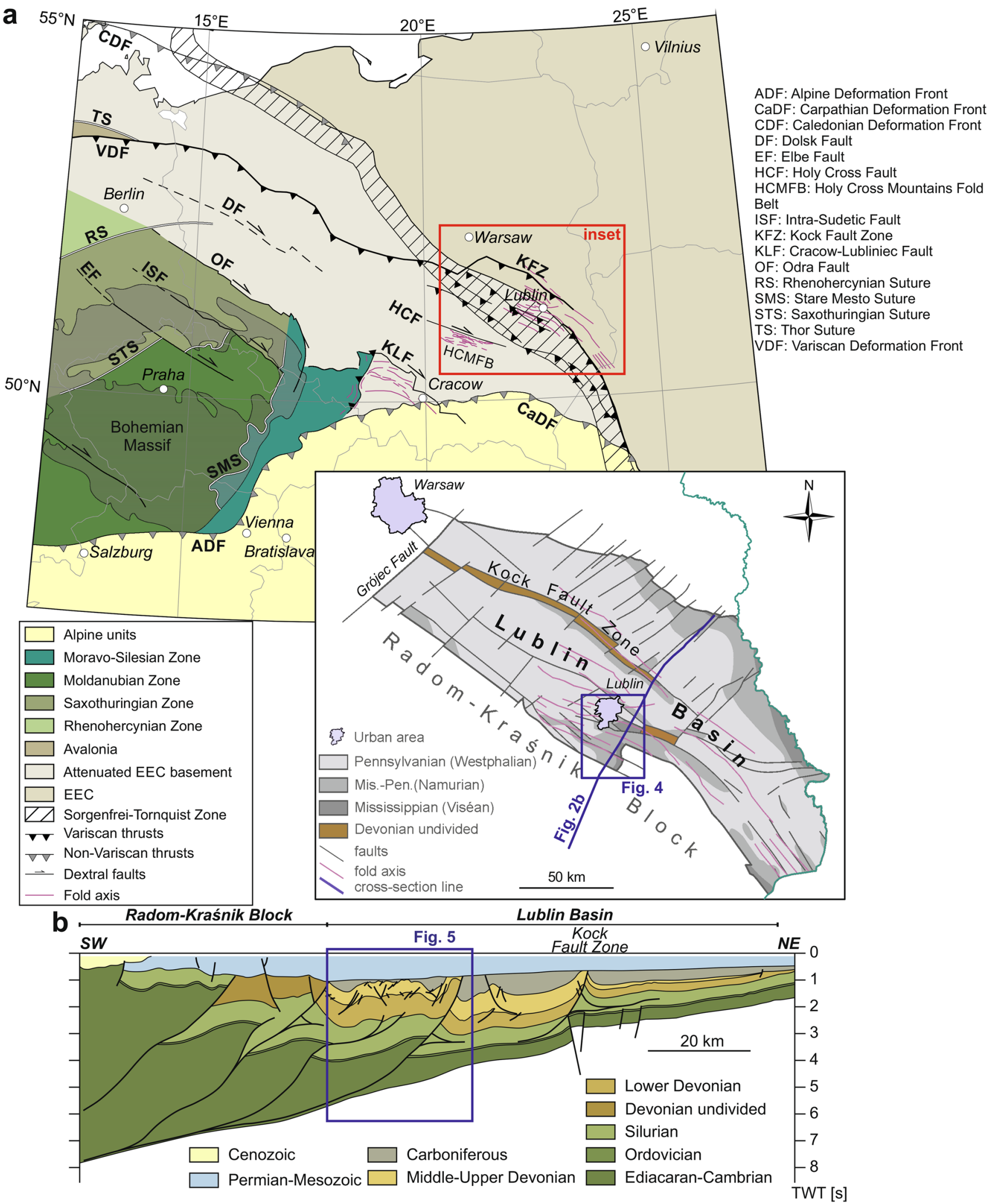

Fig. 2 a Present-day sub-Permian-Mesozoic structural framework of central Europe, except for Alpine units [compilation based on Teper (1999), Zdanowski (1999), Konon (2007), Martínez Catalán et al. (2020), Mazur et al. (2020)]; inset: generalized geological map of the
Lublin Basin (based on Waksmundzka 2010); b structure of the Lublin Basin and Radom-Kraśnik Block based on interpretation of Polan$\mathrm{dSPAN}^{\mathrm{TM}}$ regional deep seismic reflection profile (Krzywiec et al. 2017b); see a for the location of the seismic line 


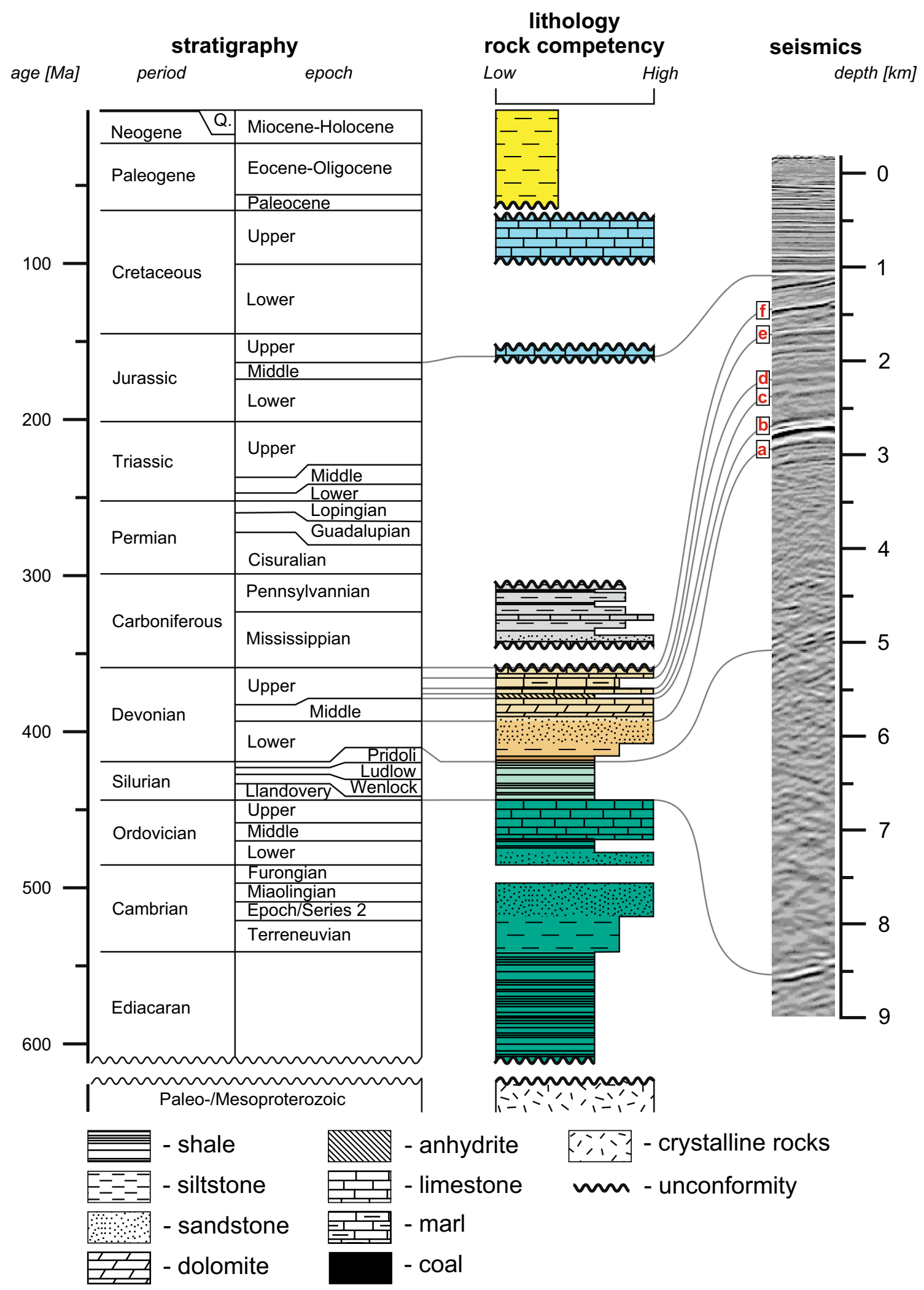

Fig. 3 Generalized lithostratigraphy of the Phanerozoic sedimentary infill within the study area and correlation of the lithostratigraphic boundaries with seismic reflections. Rock competency is marked by column width 
therein). Growth of the NE-SW-striking thin-skinned folds and thrusts detached in thick Silurian shales was accompanied by the incorporation of the LB into marginal part of Variscan tectonic wedge (Mazur et al. 2018; Kufrasa et al. 2020). Syn- and post-orogenic erosion has removed as much as up to $3 \mathrm{~km}$ of the Carboniferous and older strata and led to the formation of prominent and extensive angular unconformity (Krzywiec 2009; Kowalska et al. 2019; Kufrasa et al. 2019). Permian-Cretaceous cover, consisting of limestones, marls and dolostones, thickens from the NE towards the SW from 300 to $1200 \mathrm{~m}$. The lateral extent of the Alpine tectonics was limited to the area located to the SW of the study area and included the Mid-Polish Trough inversion and mild reactivation of some of the Palaeozoic faults within the Radom-Kraśnik Block (RKB; Fig. 2b; Krzywiec et al. 2009). Some regional long-wavelength Jurassic and Cretaceous stages of uplift have been also documented using regional seismic data that resulted, between others, in the reshaping of the Variscan unconformity (Krzywiec et al. 2018a, b). Discontinuous Cainozoic sedimentary cover reaches up to several meters of thickness and is composed of unconsolidated sediments: mudstones and sands.

\section{Data and methods}

Dense 2D seismic coverage of the area in the vicinity of the Lublin area enabled the construction of the time-structure maps for the main stratigraphic horizons (Fig. 4). A set of grids with a cell size equal to $250 \times 250 \mathrm{~m}$ was calculated based on the interpretation of 37 roughly equally distributed archive industrial seismic profiles. Stratigraphic calibration of the seismic horizons was possible thanks to the availability of the vertical seismic profile measurements (VSP) in key boreholes that penetrated Carboniferous and/or Middle-Upper Devonian strata (Fig. 4). Time-depth relations
Fig. 4 Time-structure map of the Middle Devonian top within the study area; part of the PolandSPAN ${ }^{\mathrm{TM}}$ seismic profile used for line-length restoration and LPS analysis is marked by a thick blue line. The coordinate system used in this figure is Poland CS 1992

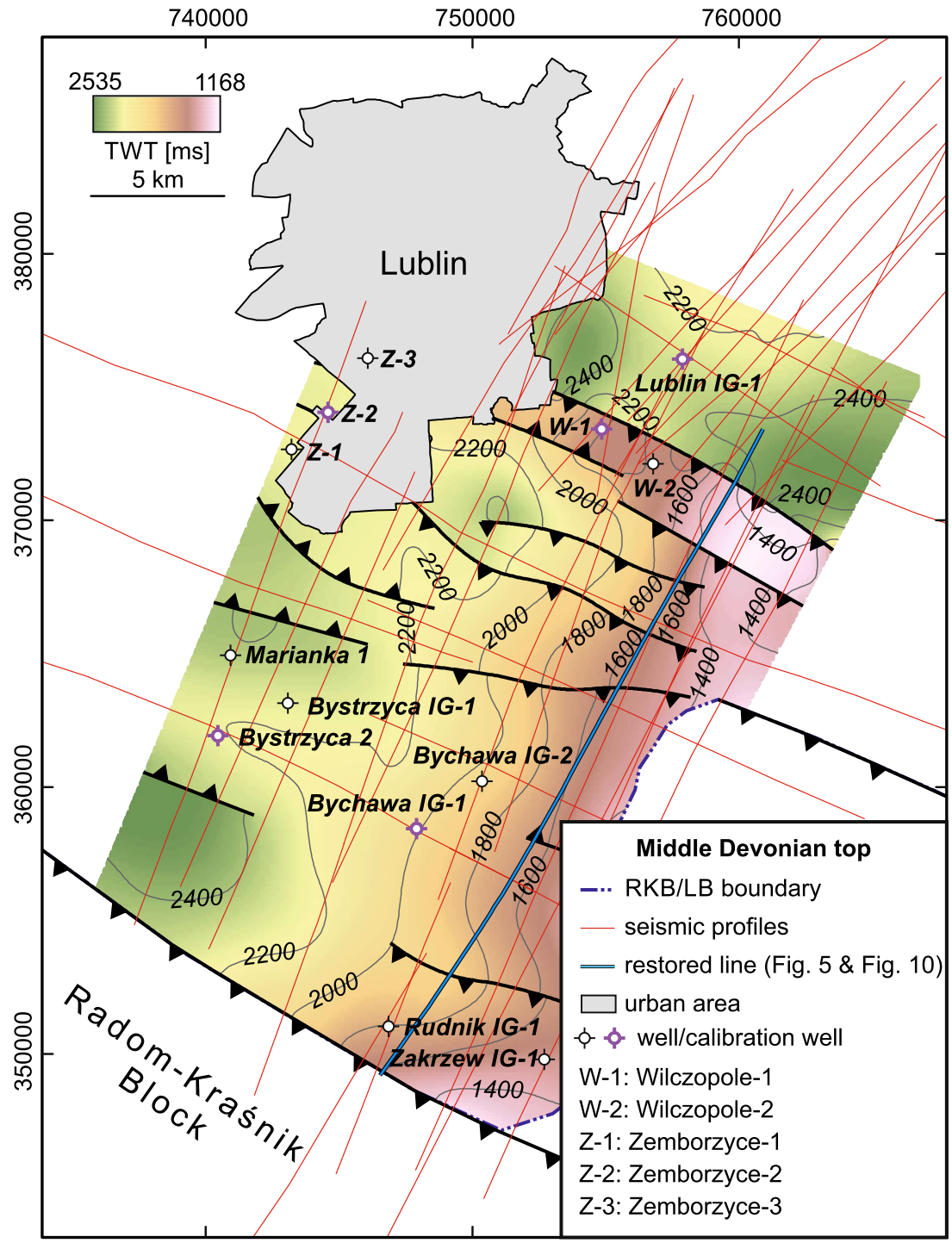


from these calibration wells were applied in the remaining boreholes. Wherever possible, tectonic structures were correlated between seismic profiles.

For the LPS analysis we selected a 30-km long portion of high-resolution depth-migrated PolandSPAN ${ }^{\mathrm{TM}}$ seismic profile 5100 (Krzywiec et al. 2017b), which is located in the central part of the LB, adjacent to the SW boundary of the LB with the RKB. Seismic image is characterized by high (15-20 m) vertical resolution within the Mesozoic and Upper Palaeozoic sections, achieved due to applying the following non-standard acquisition parameters: sweep frequency $2-150 \mathrm{~Hz}$, sweep length $16 \mathrm{~s}$, nominal fold equal to 480, and 25-m receiver/shot interval (Fig. 5; cf. Malinowski 2016). The entire PolandSPAN ${ }^{\mathrm{TM}}$ survey was time and depth (PreSDM) migrated. Below the top of Lower Devonian, notably decreased quality of seismic imaging may be observed. This is likely related to the lithological homogeneity of the Silurian-Lower Devonian sedimentary sequence composed mostly of marine mudstones and shales. Additionally, the presence of Middle Devonian evaporites (Przewodów and Giełczew Members, cf. Narkiewicz 2011) in this part of the LB hampers deeper penetration of the seismic waves.
The Phanerozoic stratigraphic column was subdivided into competent and incompetent complexes, based on their lithological composition (cf. Fig. 3). Lithostratigraphical units composed mostly of shales, mudstones or evaporites were regarded as more prone to tectonic deformation and having lower competence than packages of sandstones or carbonates (Fig. 3). The presence of strong lithological contrasts also facilitated good seismic imaging of the Middle Devonian-Carboniferous strata.

Orientation of the analysed cross-section line parallel to the direction of the late Carboniferous shortening ensured the conservation of a plane-strain state. Pin lines were placed at hinges of synclines, where minimal out-of-section material escape is expected to have occurred. From the multitude of kinematic algorithms offered by Petroleum Experts Move software, fault-bend fold was used in sequential restoration to keep bed length constant and to construct the most plausible thrust geometry based on the overlying fold shape (Suppe 1983; Connors et al. 2021). Geometry of a fault was constrained individually for each fault-related fold by forward modelling of the fold geometry in cross-section view. Once both fold's and fault's present-day geometries fitted the seismic image, they were included in restoration. A detailed

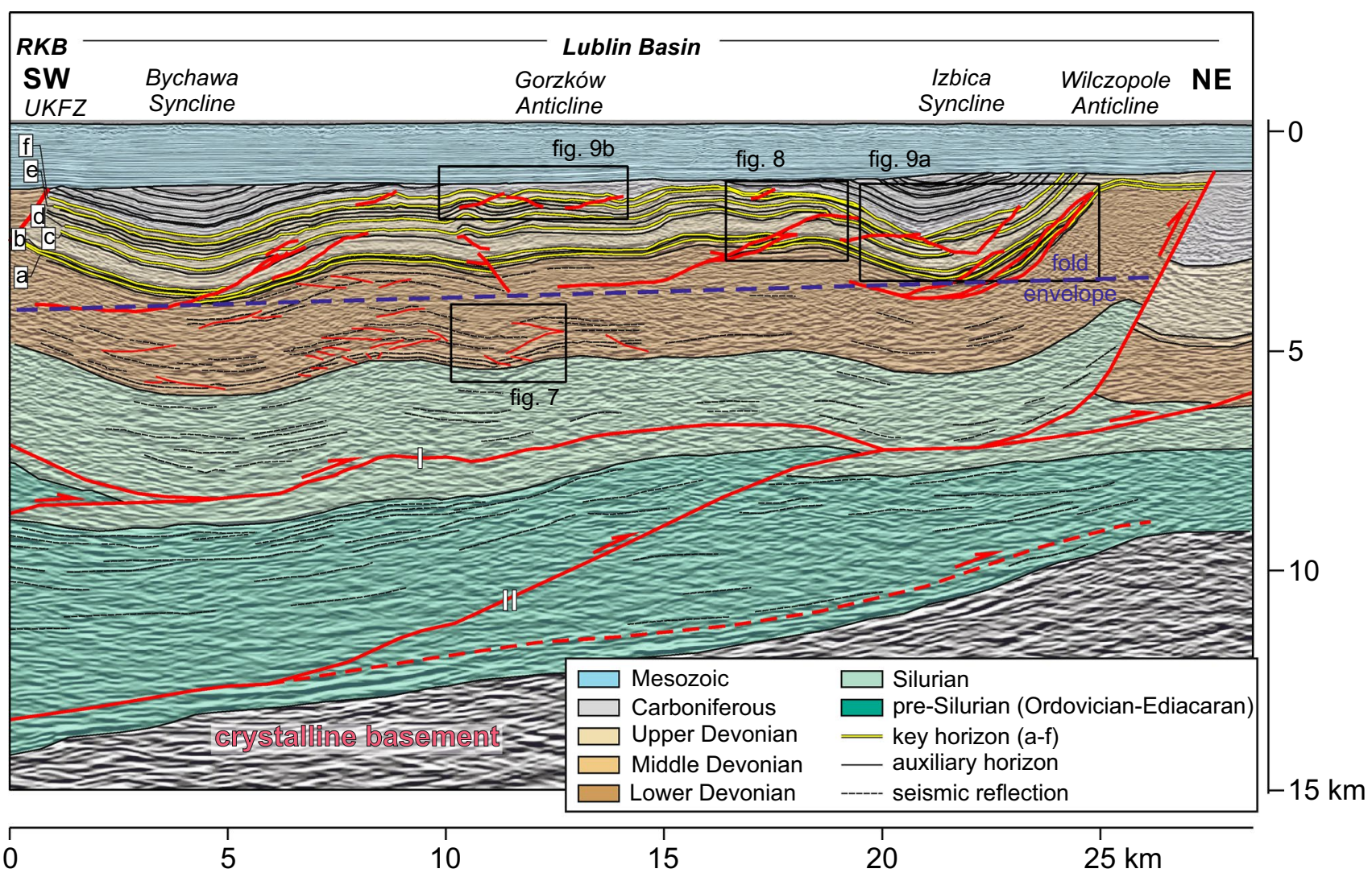

Fig. 5 Balanced geological cross-section across the southwestern segment of the Lublin Basin. Local names of structures after Tomaszczyk (2015), UKFZ Ursynów-Kazimierz Fault Zone. Zooms on areas shown in Figs. 7, 8 and 9 are indicated by black boxes. Numbers I and II refer to main detachments 
seismic interpretation permitted a selection of several key markers within the Devonian succession that were labelled a-f and used as an input for quantitative analysis (Figs. 5,7, $8,9,10)$. The percentage of shortening for horizons a-f was measured in such a way that for each key marker, the difference between horizontal distances measured between pin lines and the restored length was multiplied by 100 and then divided by restored length. LPS has been taken into account in such a way that the marker which displays the highest percentage of shortening was considered as a reference line (marker f, Figs. 5, 10). The relative difference in length between the reference line and the remaining horizons was interpreted as an effect of LPS (Fig. 10). The crosssection has been restored to a pre-Variscan state, i.e. to the pre-Carboniferous deformation geometry (Fig. 10).

\section{Results}

\section{Structural seismic interpretation: regional deformation pattern}

The investigated PolandSPAN ${ }^{\mathrm{TM}}$ seismic profile imaged deformed sedimentary cover of the LB between the Bychawa Syncline and the Wilczopole anticline (Fig. 5). A package of non-parallel reflections occurs at depth interval occupied by Ediacaran-Palaeozoic sedimentary rocks. Its upper portion reveals ca. $28-\mathrm{km}$ wide synclinorium formed in Silurian-Carboniferous strata (Fig. 5). This structure is delimited by the Wilczopole thrust and the Ursynów-Kazimierz Fault Zone (UKFZ) to the NE and SW, respectively. Central part of the synclinorium is occupied by a $16-\mathrm{km}$ wide refolded crest of the Gorzków Anticline. The flanking synclines are open, upright or gently inclined toward the foreland with amplitudes up to $1.1 \mathrm{~km}$. Such a pattern is, with some degree of confidence, traceable up to approximately $8 \mathrm{~km}$ of depth (Fig. 5). The lower portion of the seismic profile comprises reflectors related to strata located below the Ordovician top - regionally continuous and high-amplitude seismic horizon. The geometry of reflectors within this stratigraphic interval differs from those within the overlying stratigraphic package, dipping to the southwest at an angle up to $10^{\circ}$. Only below the Gorzków Anticline steeper dips of seismic reflections can be identified (Fig. 5). The deepest traceable high-amplitude seismic reflector interpreted as the top of crystalline basement descends south-westwards from ca. 9-14 km below sea level (Fig. 5).

Structural analysis of seismic data permitted to distinguish two structural complexes within the Ediacaran-Carboniferous sedimentary infill. The upper one is considered as a thrust-bounded fold train developed within the Silurian-Carboniferous strata and underlain by a basal
Fig. 6 Cartoon showing conceptual model of growth of first-order folds and thrusts during late Carboniferous Variscan shortening. Numbers I and II refer to main detachments. The black box shows the position of the analysed cross-section

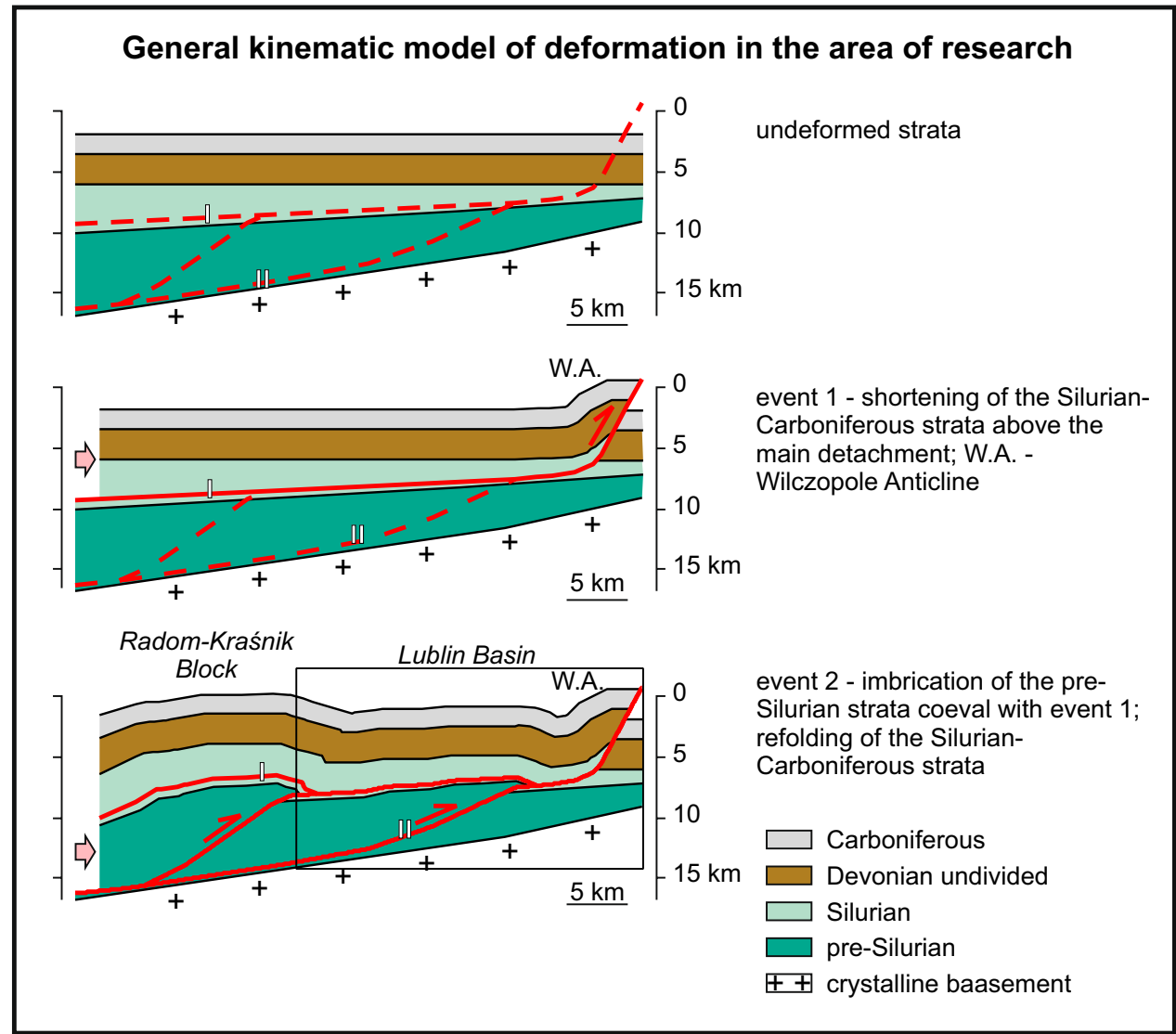




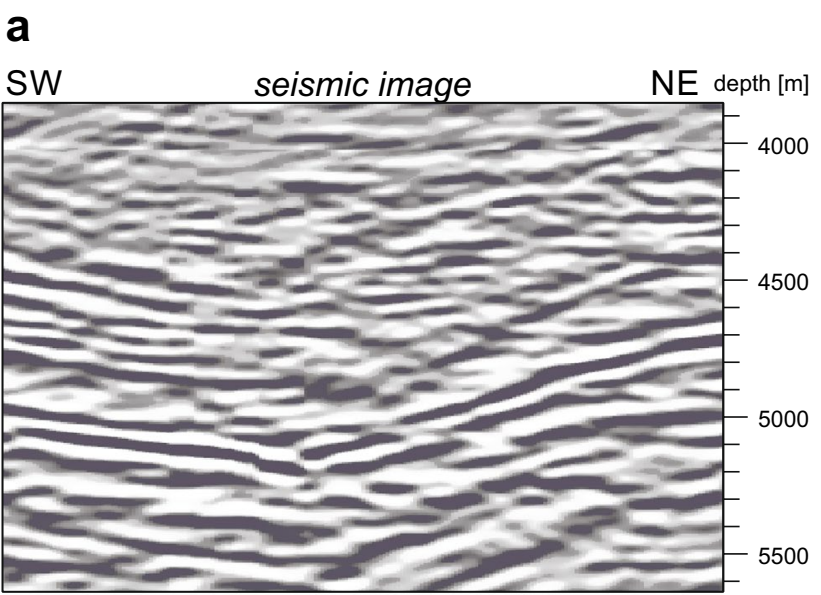

\section{b}

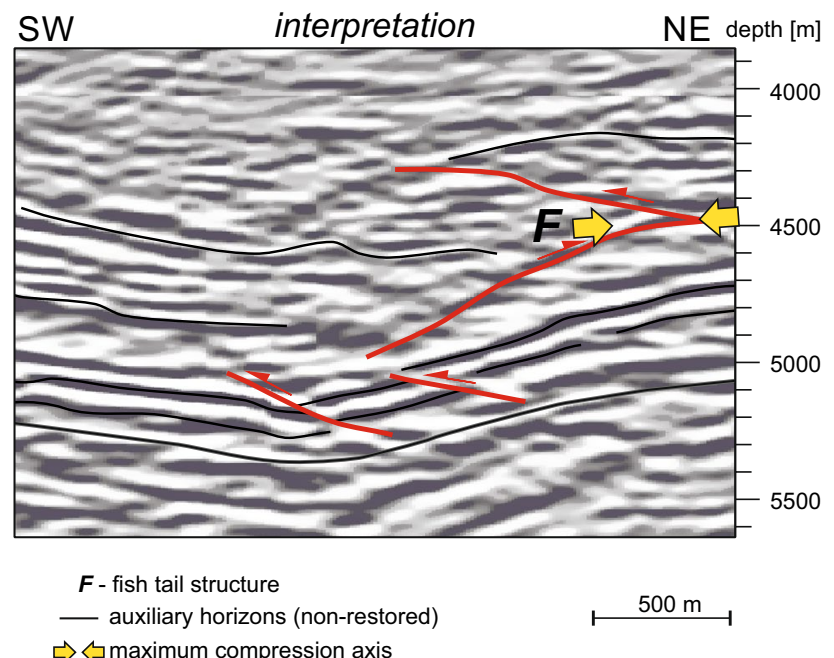

$\Rightarrow\langle$ maximum compression axis

Fig. 7 Conjugate sets of thrusts that form fish-tail structures in Silurian strata and cause localized thickening of beds. a Non-interpreted seismic image, and $\mathbf{b}$ interpretation. Note the orientation of the maximum compression axis parallel to seismic reflectors

detachment in the Silurian incompetent series (I on Fig. 5). The whole stratigraphic package within this unit is hence supposed to have experienced the same amount of shortening on the regional scale. The folded beds host multiple second-order folds and thrusts well visible on seismic data. The lower complex comprises NE-vergent imbricates formed within the Ediacaran-Silurian strata. Thrust sheets are floored by a sole thrust developed in the basal part of the Ediacaran sedimentary sequence which ramps up and merges with a roof thrust (II and I on Fig. 5, respectively).

The kinematic evolution of the synclinorium is based on the assumption that the fold envelope that connects synclinal hinges approximates pre-deformational geometry of the Lower Devonian top (Fig. 5). The proposed scenario of kinematic
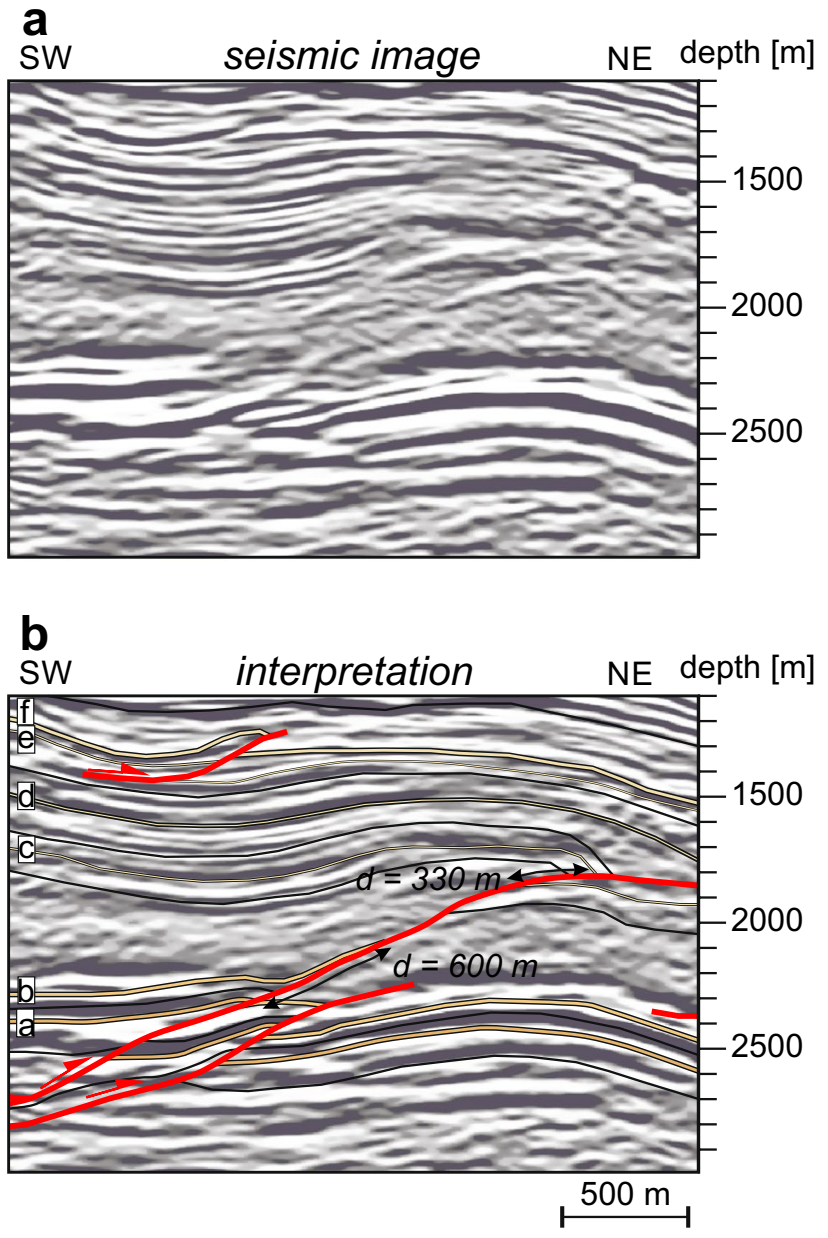

Fig. 8 Example of the thrust fault, which shows an upward decrease in fault displacement suggesting fault propagation in this direction. Symbols the same as in Fig. 7

evolution contains two structural units decoupled from each other by detachment I (Fig. 6). As the late Carboniferous horizontal compression commenced, the formation of the Wilczopole Anticline took place over the thrust ramp that branched off the detachment I (event 1, Fig. 6). Perhaps at the same time, the orogenic shortening caused imbrication of pre-Silurian strata above detachment II. The shortening transfer from lower to upper detachment was associated with concurrent folding of the overburden between the RKB and Wilczopole Anticline (event 2, Fig. 6). It can be supposed that events 1 and 2 occurred contemporaneously, as a similar amount of shortening is required to achieve present-day geometry of strata within the upper and lower structural units (ca. 1.5 and $2 \mathrm{~km}$, respectively). 

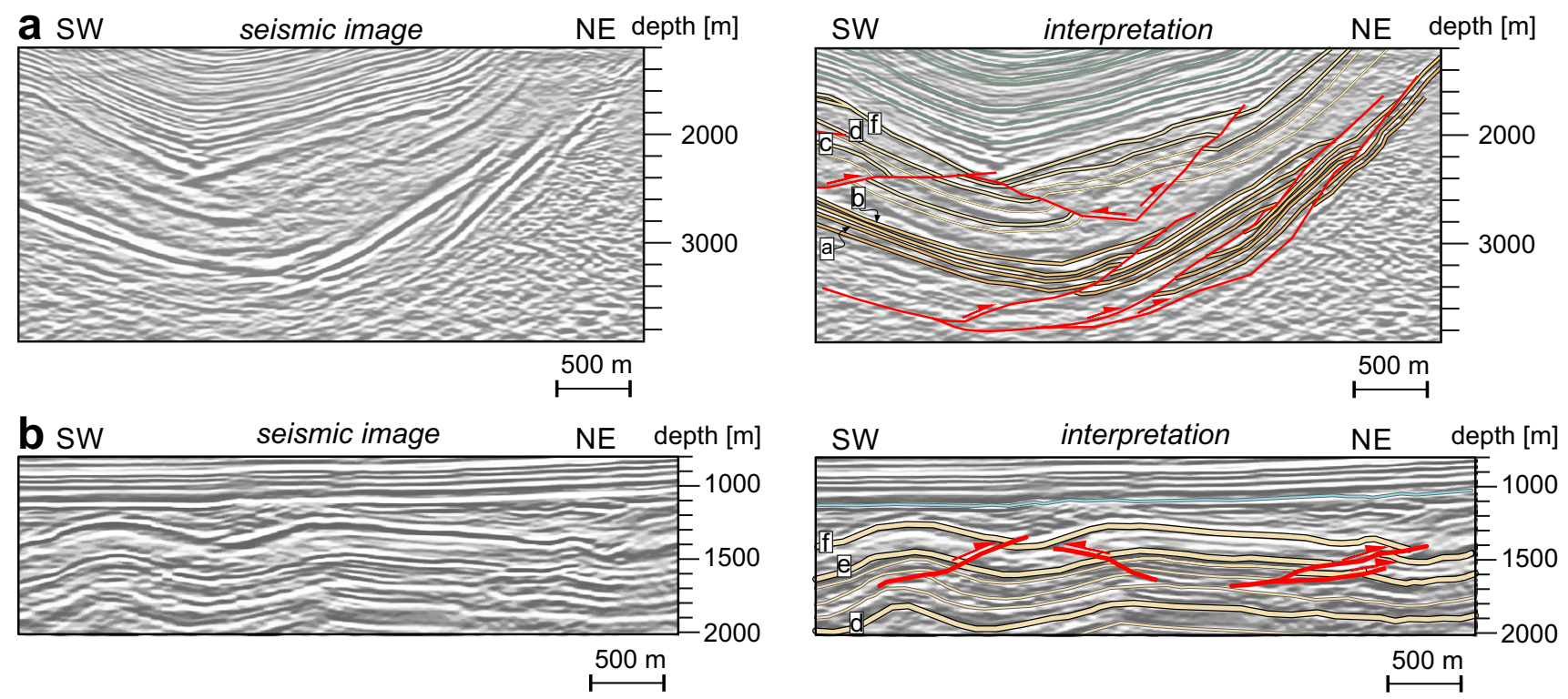

Fig. 9 Vertical differentiation of structural style: a the lithological transition from Lower Devonian clastics through Middle Devonian mixed clastic-carbonaceous-evaporitic sequence to Upper Devonian marly limestones facilitated simple shearing and formation of foreland-vergent thrusts deforming horizons $\mathrm{a}-\mathrm{b}$; symbols the same as in

Fig. 7; b uniform lithology and lack of mechanical contrasts within the Upper Devonian limestones promotes pure shear expressed by the formation of forelandward- and hinterlandward-verging thrusts between horizons $\mathrm{d}-\mathrm{f}$

\section{Structural seismic interpretation: small-scale deformations}

The analysed seismic profile reveals numerous subordinate thrusts and thrust-related folds which are concentrated in the upper structural complex that comprises ca. $3700 \mathrm{~m}$ thick interval of the Lower-Upper Devonian strata (Fig. 5). Shallower and deeper levels that embrace the Carboniferous and Silurian strata, respectively, do not show any signs of smallscale thrusting at seismic scale. However, with regards to the latter stratigraphic interval, the occurrence of small-scale deformations may be obscured by low signal-to-noise ratio and related inferior seismic imaging. The faulted interval corresponds to a multilayer of limestones, marls, shales and evaporites while the over- and underlying strata with no internal faulting comprise dominantly clastics (compare Fig. 3). This creates a distinct mechanical stratification of the Palaeozoic series that coincides with vertical lithological variations.

Fish-tail structures (cf. Drozdzewski 1979) consist of a pair of conjugate thrust faults dipping either to the NE or SW. Faults reveal a few hundred meters of fault offset, involve $500 \mathrm{~m}$ thick packages of Devonian rocks, and cause localised thickening of strata (Fig. 7). The bisector of an acute angle between conjugate thrusts marks the orientation of the maximum horizontal compression axis that generated this type of structures (Hancock and Atiya 1979). In the area investigated, axes of maximum compression derived

from fish-tail structures run parallel to the seismic horizons, which suggests that the conjugate fault system developed at the early stages of deformation.

The second-order thrusts are characterized by displacements ranging from the limit of seismic resolution (i.e. $15-20 \mathrm{~m}$ for the PolandSPAN ${ }^{\mathrm{TM}}$ profiles) up to $1400 \mathrm{~m}$. Those with larger displacements are located lower in the stratigraphic profile and offset horizons a and b (Fig. 5). The small thrusts are both foreland- and hinterland-vergent but the former dominate, in particular between markers a and c (Fig. 5). The cut-off angles are $10^{\circ}-30^{\circ}$ regardless of position within higher-order structures, which suggests their initiation in horizontal strata (e.g. Watkins et al. 2017). Upward thrusts' propagation was associated with concurrent folding in their hanging walls, as it is evidenced by the upward decrease in fault displacement and geometry of the deformed horizons (Fig. 8). It should be noticed that the highest fault displacements can be observed for the group of NE-verging thrusts in the southwestern limb of the Wilczopole Anticline (Fig. 9a), which might suggest syn-folding activity of these faults.

Within the Devonian strata, vertical differentiation of the structural style with respect to variations in lithological composition can be noticed. Conjugate sets of thrusts suggest the efficiency of distributed shortening in lithologically homogeneous strata, such as Lower Devonian mudstones or Upper Devonian carbonates (Figs. 7, 8, 9b). By contrast, mechanical heterogeneity related to the upward transition 


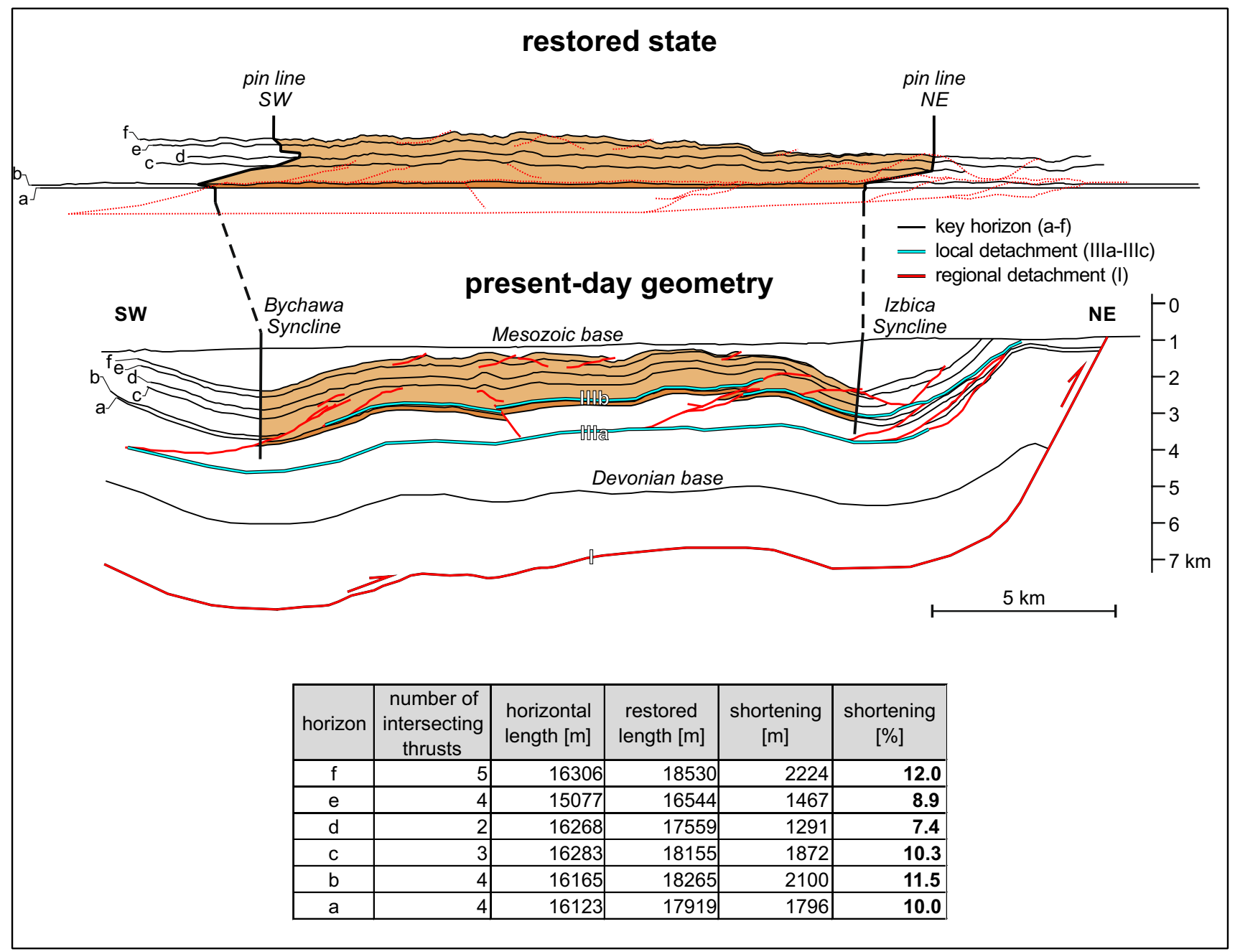

Fig. 10 (Top) Geometry of horizons a-f restored to pre-Variscan folding and thrusting assuming bed-length conservation. Shortening was estimated for fragment located between pin lines. Note regional thinning of the Upper Devonian strata toward NE, the impact of simple shear on the geometry of the restored pin lines between horizons a-c. Non-parallel geometry of the restored horizons may point to the localised efficiency of distributed shortening. (Middle) Generalized

from Lower Devonian clastic sequence to Upper Devonian marly limestones favoured preferable conditions for thrust imbrication to occur (Fig. 9a). Thus, the mechanical stratification of the Lower-Upper Devonian multilayer is interpreted here as the main reason for the predominance of SWverging thrusts in this stratigraphic interval (Figs. 9, 10).

\section{Cross-section restoration}

To quantify the amount of restorable seismic-scale strain accommodated by each horizon along with the PolandSPANTM seismic profile, we carried out the sequential restoration, following constant line-length and plane-strain assumptions. The top of Upper Devonian (f on Fig. 5) fragment of the cross-section shown in Fig. 5. Note position of local detachments IIIa and IIIb delimiting zone deformed by simple shear. (Bottom) A chart summarizing results of shortening calculations. Up to $5 \%$ difference in line length for horizons a-f correlates with the number of thrusts that intersect each horizon. Hence, it is inferred that thrusting-related LPS might be responsible for mismatching horizons' length

was chosen as a reference horizon, as it is the shallowest seismic reflector traceable throughout the upper structural complex and displays the greatest length after restoration. Following the applied regional tectonic model, the bulk of the Variscan shortening has been accommodated in structures detached above Silurian incompetent rocks (Krzywiec et al. 2017b). The majority of thrusts resolved by seismic data within the Devonian strata reveals flat-ramp-flat geometry (Fig. 5). They link two local detachments (Fig. 10): ca. $700 \mathrm{~m}$ below the Lower Devonian top (IIIa), and ca. $50 \mathrm{~m}$ above the Middle Devonian top (IIIb). These detachment horizons are probably confined either to the presence of fine-grained strata in the Lower Devonian strata (IIIa), or mixed evaporitic-shaly intervals in the Upper Devonian 
sedimentary strata (IIIb). The presence of local detachments within the Devonian succession in the area investigated has been already suggested (Kufrasa et al. 2020).

The restoration of horizons a-f reveals their corrugated geometry and differences in line length (Fig. 10). Thinning of the Devonian rocks to the NE follows regional forelandward tapering of the Palaeozoic sedimentary sequence (Kufrasa et al. 2020). Length of horizons was measured between the pin lines located in the hinge of Izbica and Bychawa synclines (Fig. 10). The horizon $\mathrm{f}$ is the shallowest one not affected by the post-Variscan erosion and hence the last that permits a reliable line-length restoration. In the ideal case, after restoration all horizons should reveal equal length. However, results of the line-length restoration, show that the shortening measured between axes of the Bychawa and Izbica synclines oscillates between 7.4 and 12\% (Fig. 10). The zig-zag shape of initially straight pin lines between horizons a-c after restoration is interpreted as an effect of increased simple shearing due to competency contrasts between Lower Devonian clastic rocks and Upper Devonian limestones.

The apparent mismatch in the percentage of estimated shortening, coupled with local deviations from expected layer-cake geometry consisting of equal-length layers points to a mechanism of deformation not resolved by seismic data, which is here interpreted as LPS and/or buckling of subhorizontal strata. Minor differences in restored lengths of markers $\mathrm{a}, \mathrm{b}$ and $\mathrm{c}$ may result from the incorporation of the frontal portion of the hanging wall of the out-of-syncline thrust in the core of Bychawa Syncline into the procedure of shortening analysis. This out-of-syncline thrust introduces extra fragments of the horizons $\mathrm{a}-\mathrm{b}$ into part of the crosssection subjected to line-length analysis (Fig. 10).

\section{Discussion}

\section{Quality of seismic image}

First, we raise the question of whether the vertical stratification of second-order thrusts and conspicuous line-length mismatch in the restored state may result from inadequate seismic acquisition and processing acquisition and rather than geology? The second-order thrusts disappear at depth and this may be attributed to the loss of seismic resolution with depth. However, high-end acquisition parameters of the PolandSPAN ${ }^{\mathrm{TM}}$ survey were determined to illuminate deeper levels and hence to overcome this issue. In addition, the visibility of the small thrusts within the affected interval does not diminish with depth. The velocity model used for PolandSPAN ${ }^{\mathrm{TM}}$ seismic data Pre-Stack Depth Migration was based on velocity information from numerous deep wells out of the study area and obtained depth subsurface image was calibrated by regional well stratigraphy. Therefore, it can be concluded that our interpretation of the seismic image and cross-section restoration are not affected by seismic-data quality and processing and reflect true geological patterns. In fact, the resolution and imaging accuracy of PolandSPAN ${ }^{\mathrm{TM}}$ seismic data surpass the resolution of any other seismic data acquired within the LB, including also several 3D seismic surveys (cf. Antonowicz et al. 2003; Krzywiec et al. 2017b; Kufrasa et al. 2018, 2020).

\section{Structural style of the LB as a function of mechanical stratigraphy}

The results of seismic interpretation and cross-section restoration point to mechanical stratification of the Ediacaran-Carboniferous strata as a principal factor that controlled the process of deformation in the LB in the late Carboniferous. This study supports the concept of the Variscan shortening transfer from the Holy Cross Mountains Fold Belt to LB, via thrust ramp that links contemporaneously activated detachments I and II (Czarnocki 1938; Lamarche et al. 1999; Antonowicz et al. 2003; Konon 2006, 2007; Szaniawski et al. 2011; Krzywiec et al. 2017b; Mazur et al. 2018). Thrust imbrication operated effectively in lithologically and mechanically heterogeneous strata by the propagation of forelandward-vergent thrust faults. This phenomenon occurred mostly in mixed Ediacaran-Silurian clastics and carbonates, and mudstones in the upper part of the Lower Devonian which pass upward into Middle-Upper Devonian sandstones, evaporites, marls and carbonates. Thrusting in the lower structural complex seems to be facilitated by north-eastward thinning of pre-Silurian strata and shallowing of the crystalline basement that might have prevented the transfer of orogenic shortening further to NE. Numerical simulations of sheared layer bounded by weak surfaces illustrate preferable development of forethrusts (Davies and Fletcher 1990). The observed structural style of the lower structural complex and the stratigraphic interval between detachment IIIa and horizon c demonstrates this phenomenon in LB. The restored geometry of pin lines between markers a and c supports the efficiency of simple shear within this stratigraphic package (Fig. 10). This interpretation confirms the results of recent studies based on subsurface data of the structural style of the Variscan FTB developed above the SW slope of the EEC (Krzywiec et al. 2017a, b; Mazur et al. 2018; Kufrasa et al. 2020).

Mechanical homogeneity of the Silurian and lower portion of Lower Devonian stratigraphic packages facilitated accommodation of Variscan contraction by distributed shortening. The strata between detachments II and IIIa occupy $50-60 \%$ of the total thickness of the Palaeozoic sedimentary sequence, so it is plausible that this weak complex controlled 
formation and geometry of the fold train that builds up the synclinorium. This conclusion might be supported by the upright geometry of first-order folds.

Distributed thrusting that creates multiple small indentations of lithologically homogeneous beds and hence shortens the involved rock formations yet without nucleation of first-order thrusts or folds shall be considered a mechanism of pure shear on a formation scale operating before the slip was transferred away from the advancing backstop along with the detachments I and II. The orientation of maximum compression axes derived from observed fault geometries point to initial propagation of foreland- and hinterland-dipping thrusts which were consecutively passive folded due to long-wavelength folding. Refolded conjugate fault systems that record early phases of orogenic shortening were also reported from the more internal part of the Variscan FTB, in the late Palaeozoic Holy Cross Mountains Fold Belt, where Palaeozoic strata crop out at the surface (Konon 2006). There the development of conjugate faults due to layer-parallel compression commenced either prior to or synchronously to initiation of folding in the Upper Devonian well-bedded limestones. Evidence for analogous process in lithologically and stratigraphically comparable strata was found at seismic scale in the north-eastern limb of the Bychawa Syncline (Figs. 5, 7). Fish-tail structures described in the external portion of the Variscan orogen were reported from Ruhr Basin, which is located at the equivalent structural position as the LB (Wrede 2005).

\section{Evidence for LPS from cross-section restoration}

Lithological and mechanical stratification of a rock package undergoing compressional deformation favours strain partitioning. Experimental investigations suggest that if a multi-layered sequence embedded in homogeneous strata is subjected to compression, it deforms by imbrication, while the surrounding rocks deform mainly by penetrative strain, buckling or formation of fish-tail structures, depending on competency (Ramberg 1963; Davies and Fletcher 1990; Tavarnelli 1997; Soleimany et al. 2013). Net shortening must balance in the whole rock sequence (Ace et al. 2020). The length mismatch in restored horizons may reflect uncertainty related to flaws in structural interpretation, presence of additional detachments, or occurrence of LPS (e.g. Watkins et al. 2014; Zamora-Valcarce and Zapata 2015; Geiser 1988). The uncertainty related to ambiguous geometry of the horizons was addressed in this study by including only seismically well-imaged markers a-f into line length analysis across the restored fragment of the cross-section (Fig. 5). The presence of multiple detachments within the Ediacaran-Carboniferous strata of the LB was suggested previously both in LB (Krzywiec et al. 2017a, b; Mazur et al. 2018; Kufrasa et al. 2020), as in the Holy Cross Mountains Fold
Belt that occupies a more internal portion of Variscan FTB (Konon 2006). This study takes this concept further, in a frame of sequential restoration. The resultant model yields satisfactory fit with the seismic image and admissible geometry of the restored markers a-f if the presence of at least four detachments levels is considered (I to IIIb, Figs. 5, 10). However, even then minor differences in the percentage of calculated shortening for horizons a-f remained in the model (Fig. 10). A fault-bend folding algorithm used in structural modelling keeps bed length constant; hence the mismatch in horizons' length is interpreted as the effect of buckling or penetrative strain. Both these phenomena might have occurred prior to faulting and might have produced localized thickening of strata. It is difficult to separate them based solely on seismic data, and in this study, they are chiefly considered as distributed shortening. The difference in the percentage of shortening of markers a-e relative to reference horizon $\mathrm{f}$ does not exceed $5 \%$ and decreases with an increase in the number of second-order thrusts that cut each horizon (Fig. 10). Geiser (1988) concluded that, regardless of the constant bed-length assumption, restoration of purely sheared multilayer inevitably leads to line-length imbalance induced by the presence of LPS. When the restoration is completed, more competent beds should reveal longer bed length relative to incompetent intervals. In the case of the markers a-f restored in this study, pure shear is expected to operate in homogeneous, yet well-bedded Upper Devonian limestones between horizons $\mathrm{c}$ and $\mathrm{f}$, as suggested by an inventory of structures observed in this stratigraphic interval (Figs. 7a, 9). Owing to that purely sheared horizons within an individual thrust sheet should reveal an equal amount of shortening, it is allowed to interpret up to 5\% difference in length of horizons $\mathrm{c}-\mathrm{f}$ as an effect of LPS. However, this number should be treated as a minimal estimate of distributed shortening, as LPS may operate continuously in front of propagating fault, as evidenced by Tavani and Storti (2011), and thus contribute to greater bed-length mismatch. This phenomenon, however, was not accounted for in this study. Localised thickening of the lowermost portion of the Upper Devonian sequence and comparable values of shortening for restored horizons a-c may suggest local occurrence of buckling which predates thrusting (Fig. 10). It should be noted that the buckles are located above future thrusts which have propagated from the Lower Devonian strata, which may point to zones of strain concentration and the kinematic link between folding and thrusting. Such interpretation is compatible with the results of structural analyses carried out both in Variscan FTB (Konon 2006) and external part of FTBs worldwide (e.g. Tavarnelli 1997).

The differences in lengths of horizons a-f in the marginal part of the Variscan orogen may be compared with the results of studies carried out in other FTBs worldwide. For example, Weil and Yonkee (2012) investigated AMS 
fabric and cleavage fractures in Triassic clastics within the easternmost part of the Sevier FTB and concluded that about $5 \%$ of LPS was acquired prior to or synchronous with the growth of regional thrusting rooted in Cambrian shales. A slightly higher amount of penetrative strain, ranging between 9 and $14 \%$, depending on the lithological composition of the deformed strata, was reported from the Glen Lyn footwall syncline located in the transition zone between the Appalachian orogen and Appalachian Plateau (Whitaker and Bartholomew 1999). Nearly identical values (10-15\% of LPS) were reported from Appalachian Plateau by Ace et al. (2020) based on results of seismic interpretation combined with cross-section restoration. The LPS estimates derived from this study are, however, slightly lower than those obtained in the AMS-based study in the outer part of Pyrenean FTB (16-23\%; Sans et al. 2003). This discrepancy may arise from the lithological difference between the carbonate-dominated Devonian strata in the LB and the clastic Palaeogene succession in the Pyrenees.

\section{Summary}

Newly acquired high-quality seismic profile from the central part of the LB allowed for detailed characterization of Variscan (late Carboniferous) deformations affecting Upper Palaeozoic sedimentary rocks, and relationships between small-scale and regional structures. Mechanical stratigraphy governed strain partitioning within the multilayer of Ediacaran-Carboniferous age. Ediacaran-Silurian and Lower-Upper Devonian sedimentary rocks are considered as mechanically stratified packages subjected to thrust imbrication during Variscan shortening. As a result, a series of forelandward-vergent thrusts formed to link the lower and upper detachments and keep the thrust system balanced. Stress acting on homogeneous strata was accommodated via distributed shortening expressed by conjugate sets of thrusts.

The combination of detailed structural interpretation and cross-section restoration enabled estimating the relative amount of LPS, which is expressed at the seismic scale by fish-tail structures and line-length mismatch in the restored section. Interpretation of the seismic data has revealed that short-wavelength folds and thrusts are dispersed in the Devonian succession. They are not confined to one specific detachment level, but, apparently, they utilize numerous local weak detachment levels. Cross-section balancing revealed up to a $5 \%$ difference in length of the restored horizons, which probably results from thrusting-related strain accommodation.

The estimated amount of LPS for the analysed crosssections is comparable to those obtained from fieldwork-based studies carried out in other FTBs. It was demonstrated that the LPS operates in marginal parts of orogenic wedges at early stages of shortening and could be quantifiable by detailed seismic interpretation and crosssection restoration.

Acknowledgements The authors wish to express their deep gratitude to reviewers: Jonas Kley and Andrzej Konon who provided insightful remarks and suggestions to this paper. The authors are indebted to Łukasz Gagała for many hours devoted to a discussion regarding the process of LPS and assistance in cross-section restoration. Constructive comments to the early version of the manuscript by Michał Śmigielski are also appreciated. Marta Godzwon is acknowledged for their linguistic remarks. PolandSPANTM seismic data were used courtesy of ION Geophysical. Petroleum Experts kindly provided Move software for cross-section construction, balancing and restoration, and IHS Markit provided software for seismic data interpretation.

Author contributions MK: conceptualization, methodology, formal analysis and investigation, writing (original draft preparation), visualization. PK: resources, writing (review and editing), supervision.

Funding The National Centre for Research and Development (project no. BG1/GAZGEOLMOD/13).

Data availability Not applicable.

Code availability Not applicable.

\section{Declarations}

Conflict of interest Not applicable.

Open Access This article is licensed under a Creative Commons Attribution 4.0 International License, which permits use, sharing, adaptation, distribution and reproduction in any medium or format, as long as you give appropriate credit to the original author(s) and the source, provide a link to the Creative Commons licence, and indicate if changes were made. The images or other third party material in this article are included in the article's Creative Commons licence, unless indicated otherwise in a credit line to the material. If material is not included in the article's Creative Commons licence and your intended use is not permitted by statutory regulation or exceeds the permitted use, you will need to obtain permission directly from the copyright holder. To view a copy of this licence, visit http://creativecommons.org/licenses/by/4.0/.

\section{References}

Ace A, McQuarrie N, Sak PB, Grundy R, Lavergne B (2020) Documenting the geometry and magnitude of shortening at the Allegheny Front: Lycoming County, Pennsylvania, United States. Am Assoc Pet Geol Bull 104:2379-2399. https://doi.org/10.1306/ 04282017325

Antonowicz L, Hooper R, Iwanowska E (2003) Lublin Syncline as a result of thin-skinned Variscan deformation (SE Poland). Prz Geol 51:344-350 (in Polish with English summary)

Brandes C, Tanner DC (2014) Fault-related folding: a review of kinematic models and their application. Earth Sci Rev 138:352-370. https://doi.org/10.1016/j.earscirev.2014.06.008 
Butler RWH, Bond CE, Cooper MA, Watkins H (2019) Fold-thrust structures - where have all the buckles gone? Geol Soc Spec Publ 487:21-44. https://doi.org/10.1144/SP487.7

Cardozo N, Brandenburg JP (2014) Kinematic modeling of folding above listric propagating thrusts. J Struct Geol 60:1-12. https:// doi.org/10.1016/j.jsg.2013.12.004

Connors CD, Hughes AN, Ball SM (2021) Forward kinematic modeling of fault-bend folding. J Struct Geol 143:104252. https://doi. org/10.1016/j.jsg.2020.104252

Czarnocki J (1938) Carte géologique générale de la Pologne, feuille 4: Kielce, Edition du Service Géologique de Pologne, 1: 100,000. Military Geographical Institute, Warsaw (in Polish and French)

Davies RK, Fletcher RC (1990) Shear bands in a plastic layer at yield under combined shortening and shear: a model for the fault array in a duplex. Geol Soc Spec Publ 54:123-131. https://doi.org/10. 1144/GSL.SP.1990.054.01.13

Drozdzewski G (1979) Main pattern of fold and fault structures in the Ruhr Carboniferous. Z Dtsch Geol Ges 130:51-67. https://doi.org/ 10.1127/zdgg/130/1979/51 (in German with English summary)

Geiser PA (1988) Mechanisms of thrust propagation: some examples and implications for the analysis of overthrust terranes. J Struct Geol 10:829-845. https://doi.org/10.1016/0191-8141(88)90098-3

Hancock PL, Atiya MS (1979) Tectonic significance of mesofracture systems associated with the Lebanese segment of the Dead Sea transform fault. J Struct Geol 1:143-153. https://doi.org/10.1016/ 0191-8141(79)90051-8

Hughes AN, Shaw JH (2014) Fault displacement-distance relationships as indicators of contractional fault-related folding style. Am Assoc Pet Geol Bull 98:227-251. https://doi.org/10.1306/05311312006

Konon A (2006) Buckle folding in the Kielce Unit, Holy Cross Mountains, central Poland. Acta Geol Pol 56:375-405

Konon A (2007) Strike-slip faulting in the Kielce Unit, Holy Cross Mountains, central Poland. Acta Geol Pol 57:415-441

Kowalska S, Wójtowicz A, Hałas S, Wemmer K, Mikołajewski Z, Buniak A (2019) Thermal history of Lower Palaeozoic rocks from the East European Platform margin of Poland based on K-Ar age dating and illite-smectite palaeothermometry. Ann Soc Geol Pol 89:481-509. https://doi.org/10.14241/asgp.2019.21

Kozłowska A, Waksmundzka MI (2020) Diagenesis, sequence stratigraphy and reservoir quality of the Carboniferous deposits of the southeastern Lublin Basin (SE Poland). Geol Q 64:422-459. https://doi.org/10.7306/gq.1532

Krzywiec P (2009) Devonian-Cretaceous repeated subsidence and uplift along the Teisseyre-Tornquist zone in SE Poland - insight from seismic data interpretation. Tectonophysics 475:142-159. https://doi.org/10.1016/j.tecto.2008.11.020

Krzywiec P, Gutowski J, Walaszczyk I, Wróbel G, Wybraniec S (2009) Tectonostratigraphic model of the Late Cretaceous inversion along the Nowe Miasto-Zawichost Fault Zone, SE Mid-Polish Trough. Geol Q 53:27-48

Krzywiec P, Gągała Ł, Mazur S, Słonka Ł, Kufrasa M, Malinowski M, Pietsch K, Golonka J (2017a) Variscan deformation along the Teisseyre-Tornquist Zone in SE Poland: thick-skinned structural inheritance or thin-skinned thrusting? Tectonophysics 718:83-91. https://doi.org/10.1016/j.tecto.2017.06.008

Krzywiec P, Mazur S, Gągała Ł, Kufrasa M, Lewandowski M, Malinowski M, Buffenmyer V (2017b) Late Carboniferous thinskinned compressional deformation above the SW edge of the East European craton as revealed by seismic reflection and potential field data - correlations with the Variscides and the Appalachians. Geol Soc Am Mem 213:353-372. https://doi.org/10.1130/2017. 1213(14)

Krzywiec P, Poprawa P, Mikołajczak M, Mazur S, Malinowski M (2018a) Deeply concealed half-graben at the SW margin of the East European Craton (SE Poland) — evidence for Neoproterozoic rifting prior to the break-up of Rodinia. J Palaeogeogr 7:88-97. https://doi.org/10.1016/j.jop.2017.11.003

Krzywiec P, Stachowska A, Stypa A (2018b) The only way is up - on Mesozoic uplifts and basin inversion events in SE Poland. Geol Soc Lond Spec Publ 469:33-57. https://doi.org/10.1144/SP469.14

Kufrasa M, Słonka Ł, Krzywiec P, Dzwinel K, Zacharski J (2018) Fracture pattern of the Lower Paleozoic sedimentary cover in the Lublin Basin of southeastern Poland derived from seismic attribute analysis and structural restoration. Interpretation 6:SH73-SH89. https://doi.org/10.1190/INT-2017-0235.1

Kufrasa M, Stypa A, Krzywiec P, Słonka Ł (2019) Late Carboniferous thin-skinned deformation in the Lublin Basin, SE Poland: results of combined seismic data interpretation, structural restoration and subsidence analysis. Ann Soc Geol Pol 89:175-194. https://doi. org/10.14241/asgp.2019.09

Kufrasa M, Krzywiec P, Gągała Ł, Mazur S, Mikołajczak M (2020) Sequence of deformation at the front of an orogen: Lublin Basin case study (Poland). J Struct Geol 141:104211. https://doi.org/10. 1016/j.jsg.2020.104211

Lamarche J, Mansy J, Bergerat F, Averbuch O, Hakenberg M, Lewandowski M, Stupnicka E, Świdrowska J, Wajsprych B, Wieczorek J (1999) Variscan tectonics in the Holy Cross Mountains (Poland) and the role of structural inheritance during Alpine tectonics. Tectonophysics 313:171-186. https://doi.org/10.1016/S00401951(99)00195-X

Le Garzic E, Vergés J, Sapin F, Saura E, Meresse F, Ringenbach JC (2019) Evolution of the NW Zagros Fold-and-Thrust Belt in Kurdistan Region of Iraq from balanced and restored crustal-scale sections and forward modeling. J Struct Geol 124:51-69. https://doi. org/10.1016/j.jsg.2019.04.006

Malinowski M (2016) Deep reflection seismic imaging in SE Poland using extended correlation method applied to PolandSPAN ${ }^{\mathrm{TM}}$ data. Tectonophysics 689:107-114. https://doi.org/10.1016/j. tecto.2016.01.007

Martínez Catalán JR, Collett S, Schulmann K, Aleksandrowski P, Mazur S (2020) Correlation of allochthonous terranes and major tectonostratigraphic domains between NW Iberia and the Bohemian Massif, European Variscan belt. Int J Earth Sci 109:11051131. https://doi.org/10.1007/s00531-019-01800-z

Mazur S, Gaggała Ł, Kufrasa M, Krzywiec P (2018) Application of two-dimensional gravity models as input parameters to balanced cross-sections across the margin of the East European Craton in SE Poland. J Struct Geol 116:223-233. https://doi.org/10.1016/j. jsg.2018.05.013

Mazur S, Aleksandrowski P, Gągała Ł, Krzywiec P, Żaba J, Gaidzik K, Sikora R (2020) Late Palaeozoic strike-slip tectonics versus oroclinal bending at the SW outskirts of Baltica: case of the Variscan belt's eastern end in Poland. Int J Earth Sci 109:1133-1160. https://doi.org/10.1007/s00531-019-01814-7

Moretti I, Callot JP (2012) Area, length and thickness conservation: Dogma or reality? J Struct Geol 41:64-75. https://doi.org/10. 1016/j.jsg.2012.02.014

Narkiewicz M (2007) Development and inversion of Devonian and Carboniferous basins in the eastern part of the Variscan foreland (Poland). Geol Q 51:231-256

Narkiewicz M (2011) Lithostratigraphy, depositional systems and transgressive-regressive cycles in the Devonian of the Lublin Basin (south-eastern Poland). Pr PIG 196:53-146 (in Polish with English summary)

Pacześna J, Poprawa P (2005) Relative role of tectonic and eustatic processes in development of the Neoproterozoic and Cambrian stratigraphic sequences of the Lublin-Podlasie Basin. Prz Geol 53:562-571 (in Polish with English summary)

Poprawa P, Krzemińska E, Pacześna J, Amstrong R (2020) Geochronology of the Volyn volcanic complex at the western slope of the East European Craton - relevance to the Neoproterozoic rifting and 
the break-up of Rodinia/Pannotia. Precambrian Res 346:105817. https://doi.org/10.1016/j.precamres.2020.105817

Price NJ, Cosgrove JW (1990) Analysis of geological structures. Cambridge University Press, Cambridge

Ramberg H (1963) Fluid dynamics of viscous buckling applicable to folding of layered rocks. Am Assoc Pet Geol Bull 47:484-505. https://doi.org/10.1306/bc743a5b-16be-11d7-8645000102c1865d

Ramsay JG (1967) Folding and fracturing of rocks. McGraw-Hill Inc, New York

Sans M, Vergés J, Gomis E, Pares JM, Schiattarella M, Trave A, Calvet F, Santanach P, Doulcet A (2003) Layer parallel shortening in salt-detached folds: constraint on cross-section restoration. Tectonophysics 372:85-104. https://doi.org/10.1016/S0040-1951(03) 00233-6

Saura E, Vergés J, Brown D, Lukito P, Soriano S, Torrescusa S, García R, Sánchez JR, Sosa C, Tenreyro R (2008) Structural and tectonic evolution of western Cuba fold and thrust belt. Tectonics 27:TC4002. https://doi.org/10.1029/2007TC002237

Soleimany B, Nalpas T, Sàbat F (2013) Multidetachment analogue models of fold reactivation in transpression: the NW Persian Gulf. Geol Acta 11:265-276. https://doi.org/10.1344/105.000001870

Stockmal GS, Lebel D, Mcmechan ME, Mackay PA (2001) Structural style and evolution of the triangle zone and external Foothills, southwestern Alberta: implications for thin-skinned thrust-andfold belt mechanics. Bull Can Pet Geol 49:472-496. https://doi. org/10.2113/49.4.472

Storti F, Salvini F, McClay K (1997) Fault-related folding in sandbox analogue models of thrust wedges. J Struct Geol 19:583-602. https://doi.org/10.1016/S0191-8141(97)83029-5

Suppe J (1983) Geometry and kinematics of fault-bend folding. Am J Sci 283:684-721. https://doi.org/10.2475/ajs.283.7.684

Szaniawski R, Konon A, Grabowski J, Schnabl P (2011) Palaeomagnetic age constraints on folding and faulting events in Devonian carbonates of the Kielce Fold Zone (southern Holy Cross Mountains, central Poland). Geol Q 55:223-234

Tavani S, Storti F (2011) Layer-parallel shortening templates associated with double-edge fault-propagation folding. AAPG Mem 94:121-135. https://doi.org/10.1306/13251335M943120

Tavarnelli E (1997) Structural evolution of a foreland fold-and-thrust belt: the Umbria-Marche Apennines, Italy. J Struct Geol 19:523534. https://doi.org/10.1016/S0191-8141(96)00093-4

Teper L (1999) Geometry of fold arrays in the Silesian-Cracovian region of southern Poland. Geol Soc Spec Publ 169:167-179. https://doi.org/10.1144/GSL.SP.2000.169.01.12

Tomaszczyk M (2015) Ewolucja centralnej części basenu lubelskiego. $\mathrm{PhD}$ dissertation, Polish Geological Institute-National Research Institute (in Polish)
Waksmundzka MI (2010) Subcrop map of the sub-Permian-Mesozoic unconformity, 1:2 000 000. In: Modliński Z (ed) Paleogeological Atlas of the sub-Permian Paleozoic of the East-European Craton in Poland and neighbouring areas, 1:2 000 000. Polish Geological Institute, Warsaw, pp 1-63

Waksmundzka MI (2013) Carboniferous coarsening-upward and nongradational cyclothems in the Lublin Basin (SE Poland): palaeoclimatic implications. Geol Soc Lond Spec Publ 376:141-175. https://doi.org/10.1144/SP376.18

Waksmundzka MI, Kozłowska A, Pańczyk MA (2021) Putative Tournaisian and Visean volcanic-sedimentary succession in the Lublin Basin, SE Poland: depositional processes, petrological characteristics and sequence stratigraphy. Acta Geol Pol 71:305-344. https:// doi.org/10.24425/agp.2020.134559

Watkins H, Bond CE, Butler RWH (2014) Identifying multiple detachment horizons and an evolving thrust history through cross-section restoration and appraisal in the Moine Thrust Belt, NW Scotland. J Struct Geol 66:1-10. https://doi.org/10.1016/j.jsg.2014.05.001

Watkins H, Butler RWH, Bond CE (2017) Using laterally compatible cross sections to infer fault growth and linkage models in foreland thrust belts. J Struct Geol 96:102-117. https://doi.org/10.1016/j. jsg.2017.01.010

Weil AB, Yonkee WA (2012) Layer-parallel shortening across the Sevier fold-thrust belt and Laramide foreland of Wyoming: spatial and temporal evolution of a complex geodynamic system. Earth Planet Sci Lett 357-358:405-420. https://doi.org/10.1016/j.epsl. 2012.09.021

Whitaker AE, Bartholomew MJ (1999) Layer parallel shortening: a mechanism for determining deformation timing at the junction of the central and southern Appalachians. Am J Sci 299:238-254. https://doi.org/10.2475/ajs.299.3.238

Woodward NB, Boyer SE, Suppe J (1989) Balanced geological crosssections: an essential technique in geological research and exploration. AGU, Washington

Wrede V (2005) Thrusting in a folded regime: fold accommodation faults in the Ruhr basin, Germany. J Struct Geol 27:789-803. https://doi.org/10.1016/j.jsg.2005.01.008

Zamora-Valcarce G, Zapata T (2015) Building a valid structural model in a triangle zone: an example from the Neuquén fold and thrust belt, Argentina. Interpretation 3:SAA117-SAA131. https://doi. org/10.1190/INT-2015-0014.1

Zdanowski A (1999) Geological Atlas of the Lublin Coal Basin 1:500 000. Polish Geological Institute, Warsaw 